\title{
A IMPRENSA CATÓLICA NO BRASIL COMO INSTRUMENTO DE APROXIMAÇÃO ENTRE O BRASIL E ROMA DURANTE A SEGUNDA GUERRA MUNDIAL
}

\section{THE CATHOLIC PRESS IN BRAZIL AS AN INSTRUMENT OF APPROXIMATION BETWEEN BRAZIL AND ROME DURING SECOND WORLD WAR}

Paula Antonia Henn' 1

Marta Rosa Borin ${ }^{2}$

RESUMO: A proposta do estudo é analisar a figura do Papa Pio XII e de que forma o Vaticano atuou no cenário internacional durante a Segunda Guerra Mundial. Partindo da análise das açóes do Pontífice Romano de 1939 a 1945, através da revista A Ordem e Revista Eclesiástica Brasileira $(R E B)$, buscamos entender a linha de ação política do Vaticano veiculada na imprensa brasileira neste período. Analisamos como a mensagem do Papa Pio XII chegou aos leitores brasileiros e de que forma foi eficaz na aproximação entre Roma e o Brasil, bem como a reação gerada em meio à instabilidade da política internacional.

Palavras-Chave: Igreja Católica. Imprensa brasileira. Papa Pio XII.

ABSTRACT: Tico-Tico The proposition of the study is to analyze the figure of Pope Pius XII and how the Vatican acted on the international scene during the World War II. Starting from the analysis of the actions of the Roman Pontiff from 1939 to 1945, through the magazine A Ordem and Revista Eclesiástica Brasileira (REB), we seek understand the line of political action from the Vatican published in the Brazilian press in this period. We analyze how the speeches of Pope Pius XII arrived to the Brazilian readers and their effectiveness in the rapprochement between Rome and Brazil, as well as a reaction generated in midst the instability of international politics.

Keywords: Catholic Church. Brazilian Press. Pope Pius XII.

\section{INTRODUÇÃO}

As A primeira metade do século XX teve grandes mudanças na política nacional, sobretudo na relação entre o Estado brasileiro e a Igreja, pois com constituição de 1891 a

1 Mestrando em História no PPGH da Universidade Federal de Goiás (UFG). Graduado em História e PósGraduado em História Cultural pela Universidade Estadual de Goiás (UEG). E-mail: prof.edson.wilson@ hotmail.com

2 Doutora em História, Professora do Programa de Pós-Graduação em História da Universidade Federal de Santa Maria.E-mail: mrborin@gmail.com 
concepçáo de estado laico rompia com qualquer ligaçáo direta com a Igreja. O sistema de padroado, ${ }^{3}$ que se estendeu sobre um longo período no Brasil, já não fazia mais sentido e a Igreja foi assumindo outra posiçăo no cenário brasileiro, pois o status de religião preponderante no país lhe conferia poder e proximidade com o povo, o que o Estado, propriamente, não possuía.

Ao se afastar da imagem de órgáo público e servidor do Estado a Igreja católica passou pelo que muitos autores chamam de romanização, voltando-se para o cerne da religiáo romana e ganhando independência nas suas ações frente ao Estado brasileiro. $\mathrm{Na}$ tentativa de reencontrar a missáo do clero e dos leigos católicos houve uma grande aproximaçáo, ou ao menos um desejo de adequar-se à Igreja Universal da qual o representante máximo era o Pontífice Romano.

A figura do Papa como líder máximo na Igreja Católica existe desde o princípio do cristianismo, sendo interpretado como um legado dado por Jesus Cristo, primeiramente a Pedro que iniciou a sucessão apostólica, seguido pelos outros Papas. Por representar a Igreja Católica no nível máximo de seu Magistério, o Pontífice Romano é o condutor dos princípios da fé e da doutrina, mas não somente isso, como também a partir do Tratado de Latráo, firmado entre o Estado italiano e a Igreja Católica, o Papa também é o chefe de Estado da Cidade do Vaticano e responde por todas as açóes políticas e diplomáticas.

Dessa maneira, ao interessar-se por adequar a fé católica no Brasil e as resoluçôes pastorais da Igreja, era necessário aos católicos principalmente ao corpo eclesiástico, que mantivesse proximidade com o Pontífice, conhecendo as instruçóes, não somente nos aspectos religiosos, mas também nos assuntos políticos assumidos pela Santa Sé. Desse modo, a imprensa foi um grande aliado nesse processo de aproximaçáo com a Igreja Universal, pois o conhecimento dos escritos e mensagens do Papa que eram retransmitidas de forma impressa serviram para legitimar e reafirmar a romanização. Nesta analise destacaremos duas revistas que veiculavam os discursos de Pio XII no Brasil a Revista Eclesiástica Brasileira e a revista $A$ Ordem. A primeira, a $R E B$, tinha uma repercussão especificamente eclesiástica, já $A$ Ordem alcançava leigos de grande formação intelectual o que também restringia o grupo de acesso ao impresso.

Mesmo que os discursos ficassem restritos ao clero, sabe-se que na primeira metade do século XX, os clérigos eram grandes formadores de opinião e de qualquer maneira a análise de outro meio de imprensa reduziria também o grupo analisado por ser um período de grande analfabetismo no Brasil. Frisamos assim que toda e qualquer análise se refere à veiculação nessas duas revistas.

O período estudado também configura mudanças na Igreja Universal, com a substituiçáo do Pontífice pelo falecimento de Pio XI, em 1939, e a escolha de Pio XII como Papa. Já no cenário internacional tinha início a Segunda Guerra Mundial quando o mundo

3 Sistema que ligava a Igreja a assuntos de ordem pública e ao Estado, e subjugava a Igreja a decisôes que eram aprovadas pelo Império como a escolha dos representantes eclesiais. As paróquias representavam o poder estatal em grande parte dos municípios e havia uma interdependência mútua. 
se encontrava em constante transformação, o que pesarosamente significava destruições, perseguiçóes e muitas mortes. E em meio à crise político-social vigente a Igreja se esforçava para atuar como sujeito internacional também nos assuntos políticos e seculares.

Fazendo uma breve contextualização dos acontecimentos da Igreja Católica Romana na figura do Pontífice também abordamos brevemente a realidade do Brasil para a compreensão de como a postura da Igreja Católica era interpretada pelos clérigos e leigos católicos principalmente nos assuntos relacionados à política internacional, ao nazismo e a Segunda Guerra Mundial.

\section{CONTEXTO POLÍTICO DO VATICANO}

A Igreja Católica passou por mudanças em 1939, com o falecimento do Papa Pio $\mathrm{XI}$, o que gerou ainda mais incertezas em meio à realidade da política internacional e a iminência do conflito mundial. Foi neste contexto que se fez necessária a realização do conclave ${ }^{4}$ para a escolha do novo Pontífice Romano.

O cardeal escolhido para assumir a representação máxima da Igreja Católica foi Eugênio Pacelli, um romano que já tinha uma longa experiência nos assuntos do papado, pois era o secretário de estado de seu antecessor e o Carmelengo ${ }^{5}$ naquele período. Ao ser escolhido, o cardeal Pacelli adotou o nome de Pio XII, demonstrando a intenção de dar continuidade ao pontificado de seu predecessor tal como plano de governo e açóes pastorais. Sendo um chefe de estado, por esse motivo, a postura do Papa, além de ser o grande representante dos assuntos religiosos, também representa as posições políticas da Santa Sé.

Ao assumir o cargo de maior importância o Cardeal Eugênio Pacelli, já conhecedor da realidade vaticana e diplomata de experiência, buscou primeiramente dialogar com alguns atores internacionais como foi o caso da tentativa frustrada de mediar o conflito entre Alemanha e Polônia. Deparando-se com o crescente acirramento do conflito, em agosto de 1939, o Papa emitiu uma mensagem divulgada pela rádio vaticana, manifestando-se em relação à esfera que antecedia o eclodir da guerra: "O perigo é iminente, mas ainda tem tempo. Nada se perde com a paz. Tudo pode ser perdido com a guerra. Que os homens voltem a compreender-se. Recomecem as negociaçôes. " Uma tentativa diplomática que mesmo sem êxito demonstrou a intenção do Papa de pedir o diálogo mesmo em meio a ânimos acirrados.

4 Reunião de cardeais após a morte ou renúncia do Papa para que outro representante seja escolhido para assumir o cargo máximo da Igreja Católica.

5 Cardeal que preside a Câmara Apostólica durante o período de Sé Vacante (em quem não há Papa) é o responsável por todos os bens e direitos temporais da Santa Sé, bem como pelas resoluções a respeito da eleição do próximo Papa.

6 PIO XII. Mensagem Radiofônica “Un’ora grave” aos governantes e aos povos no iminente perigo da guerra. 24 de agosto de 1939. Disponível em: http://w2.vatican.va/content/pius-xii/pt/speeches/1939/documents/hf_pxii_spe_19390824_ora-grave.html>. Acesso em: 02 de junho, 2016. 
Lebec (1999) afirma que diante da expansão do nacional-socialismo na Europa, as primeiras tentativas de Pio XII foram de combatê-lo, mas, por pedido de diversos cardeais, principalmente dos poloneses, o papa optou por agir de forma indireta e buscou proteger a Igreja Católica como instituição, assim como os católicos, principalmente, os das zonas de guerra e, também, manter o Vaticano como um reduto de judeus refugiados.

Em pouco tempo de pontificado, Pio XII entendeu que para manter-se no cenário mundial era necessário o máximo de cautela, por isso a posiçáo do papa condenava os atos sem condenar os autores. Como afirma Carletti (2012): A antiga e experiente diplomacia de cunho realista da Santa Sé também ensinara a Pio XII que era importante manter-se por quanto possivel acima das disputas para poder conservar margem de manobra politica suficiente em caso de mudança do jogo político internacional.

Para a Santa Sé a Segunda Guerra Mundial significava além de uma ameaça política, um risco moral e, principalmente, um perigo para todos nas naçóes em que o conflito decorria. Segundo Grigulevich (1982), a opção de Pio XII de manter silêncio diante dos acontecimentos mundiais se devia a preocupação com os fiéis e prelados que se encontravam nas zonas de conflito. Discordando de tal argumento, Deschner (1995) afirma que a posição assumida pela Santa Sé em relaçáo ao nacional-socialismo significava apoio e não imparcialidade, baseando-se no fato de que para a Igreja Católica o maior inimigo era o comunismo, que era ameaçado também pelo nazismo.

O ápice do conflito e interferência na Santa Sé foi o ano de 1943, quando Hitler invadiu a Itália, a Alemanha, num primeiro momento, ofereceu ao Papa a possibilidade de transferência, que foi recusada por Pio XII (CARLETTI, 2012, p.117). Foi nesse período que os nazistas iniciaram a perseguição aos judeus romanos que se refugiaram em prédios pontifícios. A Alemanha comunicou ao papa que não cederia a nenhuma manifestação o que teria resposta imediata com a ocupação do Vaticano considerado pelos nazistas como um "ninho de espióes" (LEBEC, 1999, p.99). O período de ocupação nazista na Itália foi caótico para o Vaticano que vivia sob a pressão de ser invadido por Hitler e ter seus cardeais e bispos assim como o Papa deportados para os campos de concentraçáo (CARLETTI, 2012, p.117).

Neste mesmo ano, o Papa Pio XII publicou uma Encíclica Mystici Corporis Christi em que levava o povo católico a refletir sobre a Igreja ser o corpo místico de Jesus, assim sendo mantinha a unidade, tal reflexão levava a conclusão de que apesar de nem todo o povo católico estar sofrendo com perseguição, morte e guerra, pela unidade gerada em Cristo todos sofriam, todos eram martirizados.

Pio XII, enquanto chefe político mantinha seus posicionamentos no cenário mundial e durante seu pontificado buscava inserir-se nas negociações de forma a extrair o máximo de seu interesse individual. Ao conduzir a Santa Sé, o Papa atuava no jogo político, principalmente durante a Guerra, buscava encontrar êxito em suas ações o que significava um passo em direção à paz ou então o sucesso das proteçóes de perseguidos das zonas de conflito. De acordo com os textos publicados na REB o Papa para os católicos, religiosos ou leigos, ao apresentar-se como líder político no meio secular é sempre revestido pela liderança espiritual. 
Durante o pontificado de Pio XII, e posteriormente a ele, houve diversas críticas a sua forma de governo por ter se mantido em silêncio mesmo diante dos abusos cometidos, principalmente por parte do nacional-socialismo durante a segunda guerra mundial. Em grande medida, de fato, as açóes do papa Pio XII foram notáveis ao manter-se aquém do conflito declarado, buscando agir de maneira particular e defendendo suas motivaçóes. O confronto aberto contra Hitler era impossível já que o papa por sua vez não possuía exército, mas em contrapartida era atuante com outros recursos dos quais fez uso como seus discursos, textos e influências para denunciar seus descontentamentos. Analisamos através das revistas $A$ Ordem e da Revista Eclesiástica Brasileira como a posição da Igreja foi expressa no Brasil, em meio à realidade da Igreja local.

\section{CONTEXTO CATÓLICO NO BRASIL}

Nos anos de 1930, a Igreja no Brasil passava por um período de reaproximação com o Estado, já que a Constituição de 1891 concedeu autonomia à Igreja. O povo brasileiro, em grande maioria católica, via no clero, tanto sacerdotes, bispos e no próprio Papa, a figura patriarcal que afirmava a tradição e assegurava a estabilidade política e educacional da família brasileira, em um tempo de mudanças e insegurança.

Com as transformaçóes e realocaçóes políticas que aconteciam no Brasil, principalmente no que se relacionavam à separação do Estado e da Igreja, os católicos buscaram reorganizar-se e para isso se voltaram a Roma, o que causou algumas mudanças.

Com a instituição do Estado laico e o fim do padroado os clérigos tiveram que encontrar outras maneiras de fazer com que a Igreja não perdesse seu lugar na sociedade, pois a grande maioria dos brasileiros dizia-se católica romana. No início do século XX, foi esse o grande interesse eclesiástico, o de que a Igreja assumisse um lugar de destaque em meio à população mesmo que diante das mudanças. Esses processos levaram bispos, dentre eles Dom Sebastião Leme, a incentivar os católicos na inserção nos meios seculares. As ideias dos líderes católicos foram reforçadas pelo Papa Pio XI quando conclamou e incentivou a criação dos grupos de Ação Católica7em todo o mundo. Segundo Flaksman e Kornis (1984, p. 511), "Pio XI sugeria a instalação de um movimento mundial com ramificaçóes em vários países [...] cuja tarefa seria evangelizar as naçóes, como uma extensão do braço da hierarquia eclesiástica”. Como afirma Aline Coutrot (2003, p. 344).

Enquanto as declaraçóes episcopais são uma constante da história da Igreja, uma nova forma de expressão organizada dos cristãos apareceu no século XX: os movimentos leigos. Sem dúvida, os séculos passados conheceram uma multiplicidade de obras dirigidas por notáveis e de associaçóes de caridade, mas os movimentos confessionais são de uma outra natureza. Criados e animados por leigos, mesmo que pastores e capeláes exerçam neles uma função importante, são representativos das aspiraçốes espirituais e humanas de seus membros. Os movimentos

$7 \quad$ A Ação Católica tem os significados de apostolado católico geral e apostolado social. Pio XI vai procurar concretizála oficialmente, em 1935, de modo especial na Itália e no Brasil, como uma organização distinta de todas as outras organizaçóes católicas, contando com outras auxiliares, e comportando uma estrutura própria e metodologia correspondente, a qual visava à colaboração ou participaçáo do leigo no apostolado da hierarquia da Igreja. 
como tais são lugares de formação total, particularmente cívica, extremamente rica, pois que ela se encarna em açóes concretas desenvolvidas em comunidades.

Caldeira (2011) afirma que um dos meios mais incentivados pelo clero foi o movimento de intelectuais católicos que formaram o Centro Dom Vital aonde desenvolveram a revista $\mathrm{A}$ Ordem que tinha como um grande objetivo discutir assuntos relacionados à religião católica, defendendo e difundindo ideais cristãos.

Neste período o maior meio de difusão das ideias e mensagens pontifícias era a imprensa que no meio eclesial se fazia presente em muitas dioceses, assim como revistas e periódicos seculares que tinham como princípios a divulgação de ideias católicas por intelectuais e religiosos da época. Uma das ferramentas usadas por Pio XII eram as mensagens radiofônicas principalmente com os assuntos relacionados às açóes políticas e ao cenário mundial, essas mensagens não chegavam ao Brasil de outra maneira se não por meio da transcrição e veiculação na imprensa.

Durante o pontificado de Pio XII, o Brasil vivia o período do Estado Novo, época da política de nacionalizaçáo e unificaçáo do país, assim como de combate ao integralismo e ao comunismo (CARNEIRO, 1988).

\section{REVISTA A ORDEM}

Com o grande incentivo do clero para que os católicos leigos assumissem uma posiçáo de destaque no cenário brasileiro fortalecendo também as lideranças nas estruturas católicas desde as primeiras décadas do século XX, Jackson Figueiredo reuniu intelectuais católicos a fim de formarem um grupo organizado com a intenção de atuar de forma mais eficaz junto às forças políticas. Não somente as autoridades religiosas, mas também os leigos começaram a ganhar papel de destaque na estrutura do catolicismo brasileiro (OLIVEIRA, 2016).

A revista $A$ Ordem nasceu em 1922, e durante o período analisado, de 1939 a 1945, teve como editor-chefe Alceu de Amoroso Lima. Carolina Dantas (2010) afirma que, mesmo sendo órgão de imprensa e assim dotado de liberdade nas ediçóes, a revista sempre prezou pela obediência eclesiástica vendo principalmente no bispo do Rio de Janeiro, Dom Sebastiáo Leme, um líder pastoral. Outro fator de destaque era a insistência na propagação dos dogmas da Igreja, como da infalibilidade papal e a obediência ao poder espiritual e temporal dos papas, legitimando suas palavras e divulgando-as com grande apreço.

Da mesma maneira que promovia a fé católica e assuntos culturais, a revista persistia na propaganda anticomunista e em relaçáo a posiçôes dos trabalhadores defendendo as ampliaçôes das políticas trabalhistas:

A partir desse momento, assuntos como educação, ação católica, combate ao comunismo, frutos da crescente participação da Igreja na sociedade durante o governo Vargas, passaram a ser debatidos de forma mais sistemática. Alguns temas foram permanentemente divulgados, evidenciando elementos fundamentais do projeto A Ordem para o Brasil: a atuação da 
juventude, a condenação do divórcio, a crítica ao socialismo, ao marxismo e ao positivismo brasileiro, a defesa da formação e atuação de uma imprensa católica, questóes relativas ao debate fé versus ciência, críticas à Revolta Comunista de 1935 e às Revoluçóes Espanhola e Mexicana. O período correspondente ao primeiro governo Vargas (1930-1945) marcou o auge da revista A Ordem, tanto em termos de circulação quanto de influência. (DANTAS, 2010).

É analisando as publicações da revista que se vê o interesse por difundir os princípios cristãos estipulando marcas próprias do catolicismo na sociedade com discussóes e estudos mais profundos e, em certa medida, com aspectos de modernidade. Sabendo da realidade em que a Igreja Católica se encontrava, no período de 1939, com as mudanças na governança do Vaticano e com as transformaçóes na política mundial, a revista lançou um texto, com aspecto de verbete, em que falava sobre o nazismo e os motivos pelos quais os católicos não deveriam se aproximar de tal ideologia. $\mathrm{O}$ texto encerra afirmando a missão dos católicos e a fidelidade às palavras do Papa:

Informem-se os católicos, da realidade nazista aqui e ali, principalmente na Alemanha, no que respeita à liberdade espiritual e particularmente o apostolado da santa Igreja e digam depois se já pesou sobre as consciências e sobre o magistério da Fé mais insuportável tirania. Meditem a encíclica acima citada ("Mit Brennender Sorge”,) e depois de abrirem a inteligência e o coração a esse nobre, sereno, firme e doloroso depoimento de Pedro contra o sistema nazista de governo do povo e de relaçóes com o Poder Espiritual, vejam se é ainda possível a um católico dar a Hitler sequer um centímetro de sua confiança. (A Ordem, p.107, 1939)

No ano de 1940, na edição de janeiro, a revista também publicou um texto em que discute a primeira encíclica do Papa Pio XII, a Summi Pontificatus, que delimita seu plano de governo e pastoral declarando que "uma das principais causas da miserável situação que o mundo atravessa consiste na recusa de reconhecer uma regra de moral universal". A revista conclui:

Ora, o hitlerismo é um movimento inspirado no ódio dessa Civilização e no pensamento de destruí-la. É um recuo para a barbárie. Daí sua agressividade e sua obsessão da força bruta. Daí também sua mística racial, portanto sua integração no paganismo, e consequentemente imporse a nova condenaçáo com que Pio XII quis acentuar seus erros e seus perigos. (A Ordem, p.93, 1940)

$\mathrm{Na}$ edição de maio de 1944, a revista divulgou um artigo escrito por Dom Thomaz Keller publicado, primeiramente na $R E B$, em que discute a encíclica escrita por Pio XII sobre o corpo místico de Cristo abordando a necessidade de ver a Igreja em sua universalidade, demonstrando aos católicos a sua unidade independente das fronteiras. O texto de Dom Keller é mais bem abordado a seguir.

Em 1945, na edição de dezembro, a revista fez um resumo sobre os acontecimentos do ano frisando o fim da guerra e o que ganha destaque é o fato de que todo e qualquer assunto político passava primeiramente pela unidade e conceito fiel à fé católica para depois adentrar em outros aspectos das discussóes. O texto inicia:

Foi um ano decisivo para o Brasil e para o mundo. Foi o ano da paz, o ano da derrota do Eixo e da vitória dos que lutavam pela liberdade, pela justiça e pela dignidade humana. Os que se deixaram vencer pelo ressentimento ou pelo ceticismo dirão que a paz na luta contra o 
nazismo sucedeu-se a guerra branca entre os novos imperialismos. Mas aqueles para quem a guerra que acabou náo foi uma luta por palavras vazias, mas por realidades muito concretas, nas quais uma vida humana e cristã digna é impossível — esses sabem que apesar de todas as deficiências a obra da paz exige o testemunho e o concurso positivo de cada membro da comunidade humana, e principalmente de cada membro do Corpo Místico de Cristo. ( $A$ Ordem, p. 85, 1945.)

Sendo uma revista que tinha por objetivo levar a ordem para o Brasil, divulgando os princípios e reafirmando características morais a veiculação da grande maioria dos textos analisados são defensores da religião. De qualquer forma, sendo um texto de crítica literária, com assuntos sobre cultura ou filosofia havia muitas citações à doutrina católica se referindo ao Papa e a uniformidade com seu pensamento. Em grande medida, um veículo de informaçáo para esse período minimizava as distâncias entre o povo brasileiro e Roma, entre os leigos e o clero, entre o Brasil e o povo europeu agredido pela guerra.

\section{O DISCURSO DO PAPA PIO XII NA REVISTA ECLESIÁSTICA BRASILEIRA (REB)}

A Revista Eclesiástica Brasileira foi fundada em 1941 por Frei Tomás Borgmeier, no intuito de ser um instrumento de promoção da unidade de comunicação entre o clero brasileiro disperso pelo imenso território nacional com dificuldade de comunicação. A $R E B$ serviu como fórum onde padres e bispos, teólogos e pastores expuseram suas reflexões e narraram suas atividades consolidando-se como o principal órgão teológico do clero nacional (Schlenker, 2011). Especificamente, de 1941 a 1952, a REB, tinha como redator-chefe seu próprio fundador.

É possível perceber pelo texto de abertura da $R E B$ a capacidade de compreensão que a Igreja tem de si e o que a revista viria a representar. No que diz respeito à $R E B$, ela pretendia, no início de sua circulação, ser um meio de comunicação eclesiológico e de divulgação entre os de clérigos da Igreja Católica no Brasil, diferente da revista $A$ Ordem que tinha por objetivo atuar entre os intelectuais católicos de forma a ser mais presente na vida dos leigos. Como expressa o texto:

A ideia da revista obedeceu ao lema: revista do clero, feita pelo clero, para o clero. Se ela houver de atingir plenamente o seu objetivo, não devera limitar-se a ser para o clero. Há de ser feita pelo clero, auscultada aos desejos dele. Cumpre, portanto, que o mesmo clero a considere sua, que a sufrague com sua inteligência, que lhe mande artigos e comunicaçóes científicas, que aborde nela questóes pastorais e pontos de vista de atualidade. A vida é sempre um jogo de dar e receber: o coração ejeta sangue, e sangue torna a receber. $O$ pensamento publicado frutificará em outrem, suscitando novos pensamentos; não publicado, permanece estéril. (REB, p. 3, 1941)

As mensagens do Papa e a realidade da Igreja no Brasil e do mundo eram conhecidas por meio das revistas, por meio dos textos e intervençóes o clero podia conhecer um pouco da realidade internacional, principalmente em meio ao conflito da Segunda Guerra Mundial.

Ao analisar a Revista Eclesiástica Brasileira, a partir de sua criação até 1945, foi perceptível a insistência da REB em divulgar as posições adotadas pela Igreja no período da 
Segunda Guerra Mundial com muitos textos publicados sobre o Papa Pio XII falando de sua figura pastoral e política como também reproduzindo seus discursos.

Por ser um tempo de mudanças em que Pio XII assumiu o governo papal é notável o grande apreço da revista por seu antecessor, sendo que nos textos do ano de 1941 ainda está muito presente a exaltação da figura de Pio XI e suas orientações em relação à Ação Católica, reafirmadas mesmo depois de sua morte. Para a forma pastoral, certamente encontra-se explicações, mas para a análise das açôes de política externa é de grande valia a transcorrência do pontificado de Pio XI para entender as motivaçóes e posiçóes adotadas por Pio XII durante sua primazia apostólica. Os textos demonstram a forte ligaçáo que os fiéis traçavam entre Pio XII e seu sucessor o que produzia certa estabilidade para o governo em tempos de conflitos.

A revista nasceu dois anos depois que o Papa Pio XII assumiu o comando da Igreja Católica, o primeiro texto da $R E B$ em sua primeira edição chama-se Príncipe da Paz, escrito por Dom Aquino Correa, Arcebispo de Cuiabá. Em um período de conflito, entre muitas incertezas, o texto aponta a segurança personificada no Papa Pio XII. O texto afirma:

De em meio aos estadistas da guerra e da força destaca-se assim Pio XII, como o soberano da paz, da qual se fez também o mais valente arauto e paladino. Lêde-me as suas alocuçóes, as suas homilias e os seus motu próprios, a sua monumental encíclica, e sentireis em todas essas expansóes da sua grande alma, o pensamento supremo, da paz, como que a emoldurá-las num maravilhoso arco-íris de celestes cores. (CORREA, 1941, p. 4)

E de forma a convocar o povo católico brasileiro a lutar pela paz e a defender o cristianismo, o texto de abertura da revista encerra:

\footnotetext{
Levantemos nós, com o príncipe da paz, os olhos ao céu, e sigamo-lo em tudo, por entre os horrores tétricos do novo caos, a que o "príncipe deste mundo" vai arrastando os seus sequazes, em ódio ao Cristo: Contra ducem superbia, Sequamurhunc nos pricipem! (o líder do orgulho, temos que lutar contra este príncipe!) (Idem, p. 5)
}

Desta maneira a revista colocou-se ao lado do Papa exaltando a sua figura e afirmando seu poder temporal além do espiritual. Algo esperado, por ser uma revista eclesiástica e por configurar um período em que havia grande unidade com o papa e o sentido da paternidade era especialmente valioso. É prioridade da REB, pelo menos no período de 1941 a 1945, a divulgação das posiçóes, ações e discursos proferidos pelo Papa, bem como as observaçóes e destaques para o seu pontificado. No ano de 1942 a revista publicou, na seção de comunicaçóes, um texto e quase que um estudo sobre os anos decorridos desde 1939, quando Pio XII assumiu o poder. Sem que o autor fosse nominado por se tratar de uma seção própria da revista, a figura do pontífice é exaltada pela data de seu jubileu episcopal.

Dessa forma as opinióes favoráveis ao Papa e a movimentação da opinião pública brasileira favorecia a imagem do pontífice como um lutador incessante pela paz. Algo que ficava explícito nos textos e na veiculaçáo da imprensa brasileira era a ideia de que o Papa possuía, de fato, a santidade que condizia ao cargo e que seu maior desejo e legado era 
defender a religiáo e lutar pela paz. Assim como ficou expresso em seu lema de pontificado: Opus Justitiae Pax (A paz é obra da justiça).

Por meio da $R E B$ as ações político-diplomáticas do Vaticano, os acordos, as concordatas, os desentendimentos eram divulgados, assim como o crescimento das dioceses e do clero, como uma forma de manter os fiéis informados. Tal atitude, mesmo que indiretamente, gerava uma segurança em relação aos acontecimentos mundiais, pois mesmo com um conflito vigente a Igreja Católica como instituição crescia, ainda que muitos padres e fiéis fossem perseguidos pelos nazistas muitos se somavam ao número do rebanho de Pedro:

\begin{abstract}
A Holanda, para 3 milhóes de católicos, possui 7.300 sacerdotes; o Canadá, para 4 e meio milhóes, 9.000 sacerdotes; a Bélgica, para 8 milhóes e 200 mil católicos, 14.000 sacerdotes, a Itália, para 41 milhóes e meio, 62.000; os Estados Unidos, para 20.775 .000 católicos possui 31.622 sacerdotes; a França para 41.242.000 católicos, 47015 sacerdotes a Índia para 3 milhôes e cem mil católicos, 3153 sacerdotes, a Alemanha para 21 e meio milhóes, 25.700 sacerdotes; o Congo Belga, para um milhão de católicos, 671 sacerdotes; a Polônia, para 34 milhóes, 14 mil sacerdotes; no Brasil para 50 milhóes de católicos, 5 mil sacerdotes. (FARIAS, 1941, p. 348)
\end{abstract}

Sabendo que a Igreja foi usada nesse período para a efetivação do Estado Novo e o convencimento da unidade da nação (BORIN, 2010), faz-se notável que também dessa forma a revista fosse usada para estabelecer tal figura no país e gerar o tão esperado nacionalismo que o governo Vargas queria, mas dessa forma incentivando o conceito de um só povo, uma só língua, uma só religião, uma só nação.

Todo o incentivo ao desenvolvimento da Ação Católica e do pensamento político ligado à religião e o crescimento dos católicos na política esclareceu bem o processo vivido pela Igreja Católica nesse período. Mas só mesmo o desenvolvimento interno era possível se externamente oferecia-se condiçóes de sobrevivência.

Diferente de muitos historiadores que afirmam ser Pio XII o papa que mais se calou, a $R E B$ expressa uma visão distinta onde, todo e qualquer discurso, detinha citaçóes referentes ao conflito mundial. Um grande exemplo disso foi a divulgação da Encíclica Mystici Corporis "sobre o corpo místico de Cristo e nossa união com ele", produzida por Pio XII, em 1943. A revista veiculou todo o texto da Encíclica em que, primeiramente, era expresso o sentido teologal da Igreja como um corpo com membros que, unidos refletiam a imagem de Jesus Cristo e por isso resultavam nesta unidade mística. A encíclica em si parece ser puramente teologal, porém vê-se no decorrer do texto a relação feita entre a Igreja e o sofrimento de Cristo, exortando para que mesmo em meio às dificuldades do período os fiéis não se dividam, mas que busquem manter-se unidos.

Após a divulgação do texto de Pio XII, a revista publicou um estudo de Dom Thomaz Keller (O.S.B.) 8 em que retoma muitos pontos da encíclica e vai atualizando os assuntos pastorais e políticos que a Igreja Católica estava passando em sentido universal.

Move-nos... não só a excepcional importância da doutrina, mas também as circunstâncias atuais em que nos encontramos. "Sua Santidade tira primeiro três motivos das circunstâncias 
atuais, para depois falar de um quarto motivo que chama principal. O primeiro motivo é a situação de desprezo e perseguição em que a Igreja se encontra. O texto alude, sem o nomear, ao racismo nazista e às suas consequências funestas entre os cristãos. (KELLER, 1943, p. 836)

Quando Dom Keller faz uso da expressão "o texto alude, sem nomear" fica clara a sua interpretação do discurso de Pio XII e sua direta relação com o cenário político internacional. Dom Keller via o Papa como um líder que, ao pronunciar-se expressava sua posição e guiava o povo, e para aqueles que a mensagem era relevante tornava-se compreensível à posição da Igreja, contrária à guerra, as perseguições e ao nazismo. Também assim mostra-se a grande preocupação em descobrir e interpretar os textos pontifícios com a visão temporal entendendo os ensinamentos e posicionamentos políticos da Santa Sé. Destaca-se a necessidade de exacerbar a figura do Pontífice e da Igreja como um ponto de unidade no mundo destruído pela guerra:

\footnotetext{
Este espetáculo não só demonstra a admirável unidade da família cristã, mas atesta também que assim como Nós, com amor paterno, abraçamos os povos de todas as naçóes, assim também os católicos de todo o mundo, embora pertencentes a povos que se guerreiam mutuamente, olha para o Vigário de Cristo como para o Pai amantíssimo de todos que mantendo perfeito equilíbrio entre ambas as partes intendentes e guiando-se por perfeita retidão de juízo superior a todas as tempestades das perturbaçôes humanas, recomenda e defende com todas as forças a verdade, a justiça e a caridade. (Keller, 1943, p. 826)
}

Ao cessar o conflito mundial, a $R E B$ emitiu uma transcrição na íntegra da radiomensagem proferida por Pio XII sobre o fim da Segunda Guerra Mundial em que o Papa reafirma a solidariedade da Igreja com a realidade crítica que o fim da guerra desvendava: "Ajoelhemo-nos diante dos túmulos onde jazem os restos de inúmeros seres humanos que tombaram na batalha - que tombaram vítimas dos massacres desumanos ou que caíram presas da fome e da necessidade" (REB, 1945, p. 417). As palavras de Pio XII expressavam e reafirmavam seu discurso antes do início do confronto "Tudo pode ser perdido com a Guerra" de fato o resultado era esse, a perda da dignidade humana de tantos massacrados, mortos ou mutilados pelo conflito.

\section{CONCLUSÃO}

Ao analisar a veiculação do discurso de Pio XII no Brasil por meio das Revistas $A$ Ordem e REB, levando em consideração seu público alvo e sua repercussão, vê-se primeiramente o empenho das publicaçóes em ser a voz da Igreja, em um período de crise política e humana como foi o da Segunda Guerra Mundial. Apesar das dificuldades que o tempo de conflito apresenta para a comunicação, houve uma constância no conteúdo dos textos publicados sobre a Santa Sé e o Papa Pio XII, demonstrando um esforço dos dois impressos em legitimar a identidade católica de cada um e fazer com que de alguma maneira, a distância entre o Brasil e Roma diminuísse.

Ao argumentar reforçamos, insistentemente, o fato do Pontífice ser representante político e religioso, o fazemos pois, aos estudar as revistas esta união dos dois poderes em um só líder torna-se facilmente perceptível. Pio XII, ao praticar sua característica 
diplomacia expressava os cuidados aos quais se resignou por suas próprias motivaçóes de política externa e religiosas. O Papa era constantemente citado pelo clero brasileiro que, além de admirá-lo como é mais esperado, tornava-se próximo e protegido por ele, sendo muito visível o fato de enxergar no Pontífice a presença da atuação divina por meio de um líder humano.

Outro ponto que merece grande destaque na pesquisa é sobre as críticas que Pio XII recebeu ao longo da história por sua postura em relação à Segunda Guerra Mundial e sua passividade nos assuntos das destruiçôes, perseguiçóes e extermínio de Judeus. Ao analisar a divulgação das mensagens de Pio XII nas ediçóes da $A$ Ordem e $R E B$, nota-se que a interpretaçáo dos textos transcritos e veiculados tinham um caráter diretamente associado ao cenário mundial. Até mesmo encíclicas de forte tema teologal eram associadas ao conflito e a situação não somente da Igreja, mas de toda a humanidade. Este é outro fator que é fortemente expresso nos textos, a ideia da Igreja Universal e do Pastor Universal significando que o Papa não é ouvido e seguido somente pelos católicos, mas suas palavras e governança são para toda a humanidade.

Desta maneira, apesar das muitas afirmações de que Pio XII foi um pontífice que silenciou face aos acontecimentos internacionais, avaliando os textos divulgados no Brasil não é possível sustentar essa opinião, pois suas ideias e discursos chegavam ao clero brasileiro como uma grande referência e presença nos momentos de crise.

A Santa Sé, por meio de seu líder, figura determinada e forte, se fez presente no Brasil, durante o período de 1941 a 1945, por meio da imprensa católica. O clero brasileiro, que era encarregado de levar a mensagem da Igreja ao povo católico, realizava o intermédio das instruções e direcionamentos pontifícios que eram valorizados tanto quanto a figura do presidente por meio da $R E B$.

A imprensa eclesiástica brasileira se fez necessária para fortalecer a Igreja Católica do Brasil, diminuir as distâncias e levar a presença do Papa para mais perto dos sacerdotes, pais e formadores de opinião dos fiéis. Mesmo que a revista não fosse acessada por todas as dioceses brasileiras e se restringia à produção de alguns sacerdotes e bispos, ela também uniu diversos pontos que foram essenciais para a criação de uma identidade católica, para a imagem da Igreja Católica no mundo, bem como para a unidade com o Papa Pio XII.

Já a revista $A$ Ordem dava ao povo católico acesso a informação por meio da leitura aproximando-os de Roma, apresentava um pastor e pai mesmo durante o período de crise política e humana como foi o da guerra. Além de, visivelmente, a imprensa ser usada pela Igreja como uma forma de missão, ela também concedia um espaço para a religiáo na sociedade brasileira e aproximava os fiéis católicos brasileiros da rocha base da Igreja Católica, Roma e seu bispo, o Papa 


\section{REFERÊNCIAS}

ALVES, Marcio M. A Igreja e a Política no Brasil. São Paulo: Brasiliense, 1993.

BORIN, Marta Rosa. Por um Brasil católico: tensão e conflito no campo religioso da república. 2010, 65 págs. Tese (Doutorado em História) Universidade do Vale do Rio dos Sinos, Unisinos, São Leopoldo, 2010.

CALDEIRA, Rodrigo Coppe Caldeira. O Catolicismo militante em Minas Gerais: aspectos do pensamento histórico-teológico de João Camillo de Oliveira Torres. Revista Brasileira de História das Religióes. ANPUH, Juiz de Fora, ano 4, n. 10, maio 2011. 46 págs.

CARLETTI, Ana. O internacionalismo vaticano e a nova ordem mundial. Brasília: FUNAG, 2012.

CARNEIRO, Maria L. T. O anti-semitismo na Era Vargas: fantasmas de uma geração (1930-1945). São Paulo: Brasiliense, 1988.

COUTROT, Aline. Religião e política. In: RÉMOND, René (Org.). Por uma história política. Rio de Janeiro: EdUFRJ, 2003.

DANTAS, Carolina Vianna. Ordem, A. (verbete) In: ABREU, Alzira (Org.). Dicionário histórico-biográfico brasileiro pós-1930. Rio de Janeiro: FGV, 2010. Disponível em: <http://cpdoc.fgv.br/dicionario-primeira-republica> Acesso em: 11 de set. 2017.

OLIVEIRA, Alexandre de. Dom Sebastião Leme e as estratégias de atuação do catolicismo nos anos 1930. Faces de Clio. Revista Discente do Programa de Pós-Graduaçáo em História. Juiz de Fora, Belo Horizonte, v. 2, n. 4, 11 págs., jul.-dez. 2016.

DESCHNER, Karlheinz. La Política de los Papas em el siglo XX: com Dios y com los fascistas (1939-1995). Zaragoza: Yalde, 1995, v. 2.

FLAKSMAN, D.; KORNIS, M. Ação Católica Brasileira. In: Dicionário HistóricoBiográfico Brasileiro: 1930-1983. v. 1. Rio de Janeiro: Forense Universitária, FGV/ CPDOC, 1984.

GRIGULÉVICH, Iosif. El papado, siglo XX. Moscú: Editora Progreso, 1982.

LEBEC, Eric. História Secreta da Diplomacia Vaticana. Petrópolis: Editora Vozes, 1999.

SCHLENKER, Rodrigo. Breve História da Revista Eclesiástica Brasileira. Disponível em: <http://www.cih.uem.br/anais/2011/trabalhos/244.pdf>. Acesso em: 15 de setembro de 2017. 


\section{FONTES BIBLIOGRÁFICAS}

CORREA, Aquino (Dom). Príncipe da Paz. Revista Eclesiástica Brasileira, INFORMAR Petrópolis, RJ, v.1, fasc.1, pp. 4-5, mar.-jun. 1941.

DE LOURENÇO, José. A Missão da Igreja e o Pontificado de Pio XII. Revista Eclesiástica Brasileira, Petrópolis, RJ, v. 5, fasc.1, pp. 189-194, mar. 1945.

FARIAS, Romeu (Padre). Dados estatísticos sobre o número de sacerdotes em diversos países. Revista Eclesiástica Brasileira, Petrópolis, RJ, p. 348. 1941.

KELlER, Dom Thomaz. Mystici Corporis Christi. Revista Eclesiástica Brasileira, Petrópolis, RJ, v. 3, fasc. 4, pp. 835-855, dez. 1943.

Revista Eclesiástica Brasileira. Nota de apresentação. Petrópolis, RJ, v. 1, fasc. 1, pp. 1-3, mar.-jun. 1941.

Revista A Ordem. Edições de 1939 a 1945.

Artigo recebido em 30/09/2017

Artigo aceito em 12/01/2018 